\title{
Heterotrophic and mixotrophic nanoplankton predation on picoplankton in the Sargasso Sea and on Georges Bank
}

\author{
Robert W. Sanders ${ }^{1, *}$, Ulrike-G. Berninger ${ }^{2}$, Ee Lin Lim ${ }^{3, * *}$, Paul F. Kemp ${ }^{4}$, \\ David A. Caron ${ }^{3, * * *}$
}

\begin{abstract}
${ }^{1}$ Department of Biology, Temple University, Philadelphia, Pennsylvania 19122, USA
${ }^{2}$ Institut für Meereskunde, Abteilung Meeresbotanik, Düsternbrooker Weg 20, 24105 Kiel, Germany ${ }^{3}$ Department of Biology, Woods Hole Oceanographic Institution, Woods Hole, Massachusetts 02543, USA

${ }^{4}$ Marine Sciences Research Center, State University of New York, Stony Brook, New York 11794, USA
\end{abstract}

\begin{abstract}
Nanoplankton and picoplankton abundance and community grazing on picoplankton were determined in summer and autumn at several stations in a productive coastal environment (Georges Bank, NW Atlantic Ocean) and in an oligotrophic oceanic ecosystem (Sargasso Sea). Ranges of heterotrophic nanoplankton (HNAN) abundance were 1.2 to $3.6 \times 10^{3} \mathrm{cells} \mathrm{m}^{-1}$ on Georges Bank, and 2.2 to $6.8 \times 10^{2}$ cells $\mathrm{ml}^{-1}$ in the Sargasso Sea. Ranges of phototrophic nanoplankton (PNAN) abundance in these ecosystems were 1.9 to $6.0 \times 10^{3}$ and 1.3 to $4.7 \times 10^{2}$, respectively. Mixotrophic nanoplankton (MNAN), operationally defined here as chloroplast-bearing nanoplankton that ingested fluorescent tracers, comprised an average of 12 to $17 \%$ of PNAN in surface waters in both environments during August and October. Mixotrophs at specific stations constituted as much as $38 \%$ of total PNAN abundance on Georges Bank and 30\% in the Sargasso Sea. Mixotrophs represented up to $39 \%$ of the total phagotrophic nanoplankton abundance (MNAN/[MNAN + HNAN]). Community grazing impact was estimated from the disappearance of fluorescent prey surrogates (fluorescently labeled bacteria, FLB; cyanobacteria, FLC $;$ and $<3 \mu \mathrm{m}$ algae, FLA). Absolute grazing rates (total picoplankton cells removed $\mathrm{d}^{-1}$ ) on Georges Bank exceeded those in the Sargasso Sea due to the greater abundances of predators and prey. However, there was overlap in the specific grazing losses at the 2 sites (ranges = 0.08 to $0.38 \mathrm{~d}^{-1}$ in the coastal ocean and 0.05 to $0.24 \mathrm{~d}^{-1}$ in the oligotrophic ocean). Rates of bacterivory were in approximate balance with rates of bacterial production $\left({ }^{3} \mathrm{H}\right.$-thymidine uptake), but production exceeded bacterivory on Georges Bank during the summer cruise. These data are among the first documenting the impact of grazing on picoplankton in these environments, and they are consistent with the prediction that nanoplanktonic protists are major predators of picoplankton. While the proportion of phototrophs that are phagotrophic was highly variable, our study indicates that algal mixotrophy is widespread in the marine environment, occurring in both coastal and oligotrophic sites, and should be considered quantitatively in microbial food web investigations.
\end{abstract}

KEY WORDS: Nanoplankton/picoplankton interactions - Mixotrophy - Bacterivory · Herbivory · Microbial food web · Flagellates C Cyanobacteria

\section{INTRODUCTION}

Azam et al. (1983) formalized the concept of a microbial loop that recovers energy and carbon shunted

•E-mail: rsanders@nimbus.ocis.temple.edu

Present addresses:

- Department of Biology. Temple University, Philadelphia, Pennsylvania 19122, USA

-.Department of Biological Sciences, University of Southern California, Los Angeles, California 90089, USA from a phytoplankton-based food web through the bacterioplankton. Nanoplanktonic ( 2 to $20 \mu \mathrm{m}$ ) protists play a pivotal role in this scheme as conduits for the reintroduction of bacteria to pelagic food webs by acting as major consumers of bacterial biomass in most planktonic environments (Weisse 1989, Sanders et al. 1992, Shiah \& Ducklow 1995). Phagotrophic nanoplankton also ingest photosynthetic microorganisms in the picoplankton size class $(0.2$ to $2 \mu \mathrm{m})$ including chroococcoid cyanobacteria and eukaryotic algae 
(Campbell \& Carpenter 1986, Caron et al. 1991, Sherr \& Sherr 1991, Reckermann \& Veldhuis 1997). Collectively, the phagotrophic nanoplankton are known to exert considerable predation pressure on bacteria and picophytoplankton of natural communities in a range of eutrophic and oligotrophic ecosystems (Sanders et al. 1992, Sherr \& Sherr 1994, Havskum \& Hansen 1997. Caron et al. 1999)

Research characterizing grazing within microbial food webs has focused on heterotrophic (apochlorotic) nanoflagellates as the consumers within the nanoamong nanoplanktonic phytoplankton (specifically, phagotrophic activity by phototrophic protists) recently has begun to be incorporated into the microbial loop concept (Thingstad et al. 1996). Mixotrophic algae have been reported from a wide variety of marine and freshwater environments (Sanders 1991), and a potentially important contribution of these algae to community photosynthesis and predation in freshwater environments has been noted (see references in Stoecker 1998). Much less is known about the ecological significance of mixotrophy in marine ecosystems.

This gap in our knowledge is due in part to the fact that identifying mixotrophic activity by algae in natural environments requires experimental evidence of feeding Taxonomic composition of natural assemblages of nanoplanktonic algae is difficult to obtain, and thus this information is usually unavailable for estimating the contribution of mixotrophs to phytoplankton communities. Furthermore, taxonomic characterization does not necessarily provide information concerning the phagotrophic activity of mixotrophic algae at any one time or place because this activity can be induced or suppressed by a variety of conditions and/or limitations. Phagotrophy by mixotrophic algae has been identified as a mechanism for the acquisition of carbon (or energy from organic carbon), growth-limiting macroor micronutrients, or other specific growth factors such as vitamins or phospholipids (Kimura \& Ishida 1989, plankton size class. However, the role of mixotrophy

Sanders et al. 1990, Caron et al. 1993, Nygaard \& Tobiesen 1993). Given these disparate potential benefits and the methodological limitations of detecting this behavior, it has been difficult to formulate and test hypotheses concerning the distributions of mixotrophs across a range of aquatic environments

The objectives of this study were to compare predation on picoplankton in a eutrophic and an oligotrophic marine ecosystem, and to examine whether mixotrophic (phagotrophic) algae contributed to this predation impact. We determined the abundances of picoand nanoplanktonic organisms and conducted grazing experiments at several stations in a coastal upwelling environment (Georges Bank) and an oligotrophic oceanic environment (Sargasso Sea) during 2 seasons. On average, predation on picoplankton in these contrasting environments removed similar proportions of the standing stocks of bacteria and picoplanktonic phototrophs daily. Mixotrophic nanoplankton were observed in the surface mixed layers at all locations in both seasons, and they occasionally constituted a significant portion of the phototrophic nanoplankton (up to $38 \%$ ) and total phagotrophic nanoplankton (i.e. heterotrophs + mixotrophs; up to $39 \%$ ). Absolute abundances of mixotrophs were greater at the coastal stations, but the abundances of mixotrophs as a percentage of phototrophic and/or phagotrophic nanoplankton showed no clear trend with the trophy of the 2 study sites. Our findings add to the relatively few data available that estimate grazing impact on picoplankton and the importance of mixotrophic algae to this process in these marine ecosystems.

\section{METHODS}

Study sites and abundance determinations. Estimates of picoplankton and nanoplankton abundance and nanoplankton predation impacts were made in the coastal ocean of the northeast USA (Georges Bank) and near Bermuda (Sargasso Sea) during cruises in October 1990 and

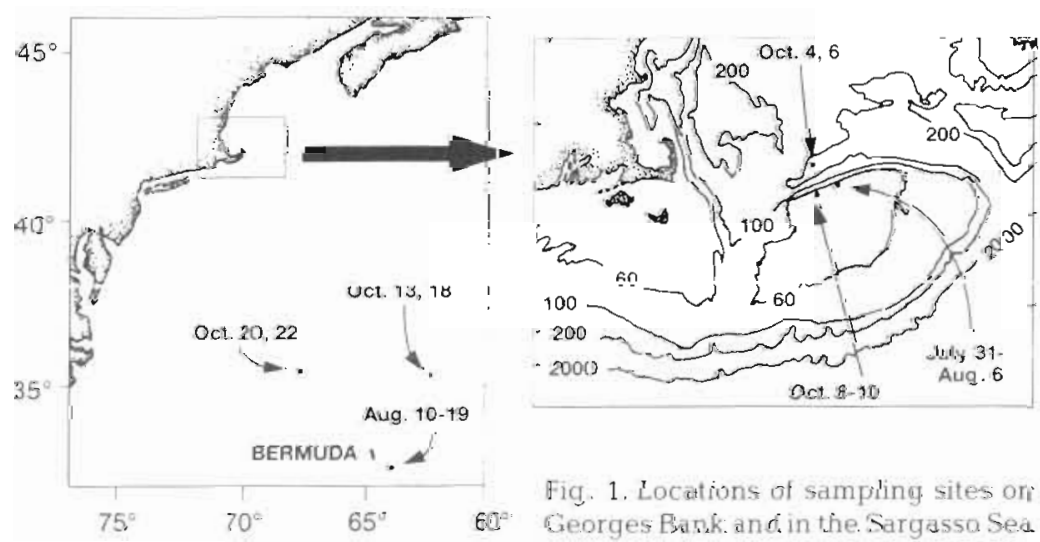
July/August 1991 (Fig. 1). Georges Bank is located approximately $125 \mathrm{~km}$ east of Cape Cod, Massachusetts. It is an area of the continental shelf typified by steep depth contours and exposure to strong tidal currents across its shallow top fBooks 1996). Geuryes Bank historically supported several important fisheries; it has been and continues to be a site of intense scientific interest and research (Stoecker et al. 1989, Sherman et al, 1996, Wiebe \& Beardsley 1996). In contrast, the Sar- 
gasso Sea near Bermuda represents a highly oligotrophic, central ocean gyre environment. Plankton communities of this ecosystem are typically strongly dominated by picoplanktonic biomass and processes (Fuhrman et al. 1989, Li et al. 1992, Caron et al. 1995).

During the October cruise, 2 stations were occupied on Georges Bank, and 2 in the Sargasso Sea north of Bermuda (Fig. 1). Observational and experimental studies were carried out on 2 dates ( 2 to $5 \mathrm{~d}$ apart) at all 4 locations. During the July/August cruise a single site on Georges Bank and one in the Sargasso Sea south of Bermuda were occupied (Fig. 1). Four experiments (2 to $3 \mathrm{~d}$ apart) were performed at each of these stations. At all stations, water was collected at 5 or 6 depths in acid-cleaned $30 \mathrm{l}$ Niskin bottles fitted with Tefloncoated springs and o-rings in conjunction with CTD casts for profiles of water column temperature and in situ fluorescence. Samples for estimates of microbial abundance were preserved with glutaraldehyde $(1 \%$ final concentration) immediately after collection and prepared within $24 \mathrm{~h}$ for enumeration by epifluorescence microscopy.

For enumerating nanoplanktonic protists, duplicate subsamples (25 to $50 \mathrm{ml}$ ) were collected on black $0.22 \mu \mathrm{m}$ polycarbonate filters and stained with DAPI (modified from Porter \& Feig [1980] by increasing final DAPI concentration to $25 \mu \mathrm{g} \mathrm{ml}^{-1}$ ). Bacterial abundance was determined from similar, but separate DAPI preparations of $<1$ to $2 \mathrm{ml}$ of seawater. Cyanobacteria were enumerated from unstained preparations using their phycoerythrin autofluorescence to identify cells (Waterbury et al. 1979). Filters for all epifluorescence preparations were sealed between a slide and coverslip with paraffin wax and frozen until counted at $1000 \times$ magnification. At least 60 and usually $>200$ cells were counted per slide. Phototrophic nanoplankton (PNAN) and heterotrophic nanoplankton (HNAN) were differentiated by the presence/absence of chlorophyll autofluorescence using separate filter sets optimized for chlorophyll or DAPI fluorescence.

Mixotrophic nanoplankton (MNAN) were enumerated in samples incubated to measure community ingestion rates using fluorescently labeled prey (see below). Subsamples were removed and $0.5 \% \mathrm{NiCl}_{2}$ was added to immobilize protists and eliminate particle egestion during fixation ( $\mathrm{J}$. Waterbury pers. comm.). Cells were then preserved with glutaraldehyde ( $1 \%$ final concentration) and prepared for epifluorescence microscopy following our procedure for protists. MNAN were operationally defined as cells that contained autofluorescent chloroplasts and 1 or more fluorescently labeled prey. Samples preserved immediately after the addition of fluorescent prey were also counted as controls for fluorescent tracers filtered on top of cells during slide preparations. The relative abundances of mixotrophs were calculated from the proportion of MNAN to total PNAN (MNAN/PNAN). The proportion of total phagotrophic nanoplankton that were mixotrophic (MNAN/[MNAN + HNAN]) was also calculated for each station.

Bacterial production. Bacterial production was estimated based on ${ }^{3} \mathrm{H}$-thymidine (TdR) incorporation into DNA modified from protocols of Fuhrman \& Azam (1982) and corrected for the recovery of pre-labeled DNA from parallel samples. Factors for conversion of thymidine incorporation to cell production were estimated in each environment during both cruises by inoculating $0.2 \mu \mathrm{m}$ filter-sterilized seawater with $0.8 \mu \mathrm{m}$ filtered seawater from the same source. Bacterial abundance was determined simultaneously with short-term TdR incorporation at $6 \mathrm{~h}$ intervals for $36 \mathrm{~h}$, and used to calculate the number of cells produced $\mathrm{mol}^{-1} \mathrm{TdR}$ incorporated. Conversion factors were $4.7 \times$

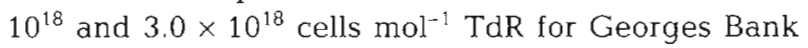
and the Sargasso Sea, respectively. Rates were corrected based on an extraction efficiency of $70 \%$ recovery of added pre-labeled DNA to sample material.

Community grazing estimates. Community-level consumption of picoplankton within the microbial food web was measured by determining the disappearance of fluorescent prey items (Pace et al. 1990). At each station, water for grazing experiments was collected at 1 depth within the surface mixed layer (Tables 1 \& 2); water for experiments was withdrawn from the same Niskin bottle used for abundance estimates at that depth.

Three types of fluorescently labeled cultured prey were prepared using 5-(4,6-dichlorotriazin-2-yl) aminofluorescein (DTAF) by the methods outlined in Sherr \& Sherr (1993) and Rublee \& Gallegos (1989). Disappearance of fluorescent prey was used to estimate the community grazing impact on different components of the microbial food web. Bacterivory was determined using fluorescently labeled bacteria (FLB) prepared from starved Halomonas halodurans $(0.8 \mu \mathrm{m})$. Herbivory was estimated with fluorescently labeled cyanobacteria (FLC) prepared from Synechococcus strain WH8012 (0.8 to $0.9 \mu \mathrm{m}$ ) and/or fluorescently labeled algae (FLA) from a spherical 1 to $2 \mu \mathrm{m}$ Nannochlorislike alga isolated from Great South Bay, New York, USA. Disappearance of fluorescent minicells (FLM, 0.6 to $0.7 \mu \mathrm{m}$ ) derived from a mutant strain of Escherichia coli (Pace et al. 1990) was used instead of FLB disappearance during the October 1990 Sargasso Sea experiments. Clumping and fading of the minicells resulted in inconclusive grazing determinations, but these prey surrogates were adequate for estimating abundances of mixotrophs. Fluorescently labeled prey were added to samples at approximately 25 to $35 \%$ of the abundances of natural prey (based on counts of the prey by 
Table 1. Specific grazing and bacterial production rates on Georges Bank and in the Sargasso Sea during the autumn cruise. Grazing rates on picoplankton were calculated from disappearance of several types of fluorescently labeled tracer: FLA $=$ fluorescently labeled algae; FLC = fluorescently labeled cyanobacteria; FLB = fluorescently labeled bacteria; nd = not determined. Mean \pm SD

\begin{tabular}{|c|c|c|c|c|c|c|}
\hline & $\begin{array}{l}\text { Date } \\
(1990)\end{array}$ & $\begin{array}{l}\text { Depth } \\
(\mathrm{m})\end{array}$ & $\begin{array}{l}\text { FLA removal } \\
\qquad\left(d^{-1}\right)\end{array}$ & $\begin{array}{l}\text { FLC removal } \\
\qquad\left(d^{-1}\right)\end{array}$ & $\begin{array}{l}\text { FLB removal } \\
\qquad\left(\mathrm{d}^{-1}\right)\end{array}$ & $\begin{array}{l}\text { Bacterial production } \\
\qquad\left(\mathrm{d}^{-1}\right)\end{array}$ \\
\hline Georges Bank & $\begin{array}{l}4 \text { Oct } \\
6 \text { Oct } \\
8 \text { Oct } \\
10 \text { Oct } \\
\text { Average }\end{array}$ & $\begin{array}{r}10 \\
10 \\
5 \\
5\end{array}$ & $\begin{array}{c}0.10 \pm 0.02 \\
0.20 \pm 0.01 \\
0.08 \pm 0.04 \\
0.18 \pm 0.08 \\
0.14\end{array}$ & $\begin{array}{c}0.07 \\
0.20 \pm 0.04 \\
0.15 \pm 0.09 \\
0.26 \pm 0.07 \\
0.17\end{array}$ & $\begin{array}{c}0.22 \pm 0.01 \\
0.38 \pm 0.02 \\
0.34 \pm 0.02 \\
0.18 \pm 0.15 \\
0.28\end{array}$ & $\begin{array}{l}0.23 \\
0.19 \\
0.24 \\
0.17 \\
0.21\end{array}$ \\
\hline Sargasso Sea & $\begin{array}{l}13 \text { Oct } \\
18 \text { Oct } \\
20 \text { Oct } \\
22 \text { Oct } \\
\text { Average }\end{array}$ & $\begin{array}{l}20 \\
10 \\
10 \\
10\end{array}$ & $\begin{array}{c}0.10 \pm 0.09 \\
0.12 \pm 0.04 \\
0.13 \pm 0.01 \\
0.18 \pm 0.02 \\
0.13\end{array}$ & $\begin{array}{c}0.07 \pm 0.02 \\
0.10 \pm 0.09 \\
0.05 \pm 0.01 \\
0.22 \pm 0.01 \\
0.11\end{array}$ & $\begin{array}{l}\text { nd } \\
\text { nd } \\
\text { nd } \\
\text { nd }\end{array}$ & $\begin{array}{l}0.032 \\
0.052 \\
0.026 \\
0.028 \\
0.035\end{array}$ \\
\hline
\end{tabular}

Table 2. Specific grazing rates on picoplankton calculated from disappearance of fluorescently labeled tracers during the summer cruise. Mean $\pm \mathrm{SD}$. Abbreviations as in Table 1

\begin{tabular}{|c|c|c|c|c|c|}
\hline & $\begin{array}{l}\text { Date } \\
\text { (1991) }\end{array}$ & $\begin{array}{l}\text { Depth } \\
(\mathrm{m})\end{array}$ & $\begin{array}{l}\text { FLA removal } \\
\qquad\left(\mathrm{d}^{-1}\right)\end{array}$ & $\begin{array}{l}\text { FLB removal } \\
\qquad\left(d^{-1}\right)\end{array}$ & $\begin{array}{l}\text { Bacterial production } \\
\qquad\left(\mathrm{d}^{-1}\right)\end{array}$ \\
\hline Georges Bank & $\begin{array}{l}31 \text { Jul } \\
2 \text { Aug } \\
4 \text { Aug } \\
6 \text { Aug } \\
\text { Average }\end{array}$ & $\begin{array}{l}- \\
2 \\
2 \\
2\end{array}$ & $\begin{array}{c}\text { nd } \\
0.18 \pm 0.01 \\
0.20 \pm 0.02 \\
0.24 \pm 0.01 \\
0.21\end{array}$ & $\begin{array}{c}\text { nd } \\
0.12 \pm 0.00 \\
0.21 \pm 0.09 \\
0.13 \pm 0.02 \\
0.15\end{array}$ & $\begin{array}{l}0.6 \\
1.2 \\
1.4 \\
1.1 \\
1.2^{\mathrm{a}}\end{array}$ \\
\hline Sargasso Sea & $\begin{array}{l}10 \text { Aug } \\
14 \text { Aug } \\
16 \text { Aug } \\
19 \text { Aug } \\
\text { Average }\end{array}$ & $\begin{array}{l}15 \\
15 \\
15 \\
15\end{array}$ & $\begin{array}{c}0.20 \pm 0.01 \\
0.20 \pm 0.07 \\
0.21 \pm 0.06 \\
0.10 \pm 0.08 \\
0.18\end{array}$ & $\begin{array}{c}0.11 \pm 0.01 \\
0.13 \pm 0.01 \\
0.11 \pm 0.04 \\
0.16 \pm 0.03 \\
0.13\end{array}$ & $\begin{array}{l}0.25 \\
0.24 \\
0.22 \\
0.22 \\
0.23\end{array}$ \\
\hline
\end{tabular}

epifluorescence microscopy prior to the addition of fluorescently labeled particles [FLP]).

For each prey type, duplicate 1 I samples were placed in 1.2 l clear polycarbonate bottles, inoculated with a single type of fluorescent prey and gently mixed. Capped bottles were incubated in an on-deck Plexiglas incubator covered with neutral-density screening to approximate light levels at the collection depths. Controls for fading of the fluorescently labeled prey, and for other non-grazing losses, consisted of sample water that was prefiltered through $0.2 \mu \mathrm{m}$ filters prior to the addition of fluorescent prey. Average decreases of fluorescent particles in the controls were $2 \%$ for FLB, $4 \%$ for FLA and $17 \%$ for FLC Incubations lasted 24 or $36 \mathrm{~h}$ at the Georges Bank and Sargasso Sea sites, respectively. Subsamples for determining FLP concentration were preserved with glutaraldehyde at the beginning and end of the incubations, filtered onto black polycarbonate filters and sealed with wax as described above. FLP were counted using epifluorescence microscopy and specific grazing rates were calculated from the rates of change in FLP abundance during the incubations after correction for non-grazing losses.

\section{RESULTS}

\section{Hydrography and abundance of pico- and nanoplankton}

The water column structure during the 2 cruises differed considerably with both site and season. The sampling site with a water depth $>100 \mathrm{~m}$ on Georges Bank during the October cruice showed strong vortical strat ification due to a thermocline starting at approximately 20 or $30 \mathrm{~m} \mathrm{(4}$ and 6 October, respectively). Fluorescence values decreased markedly below the thermocline at that site (Fig. 2). Temperature and fluorescence profiles indicated a well-mixed and slightly warmer water column at the shallower site sampled on 8 and 


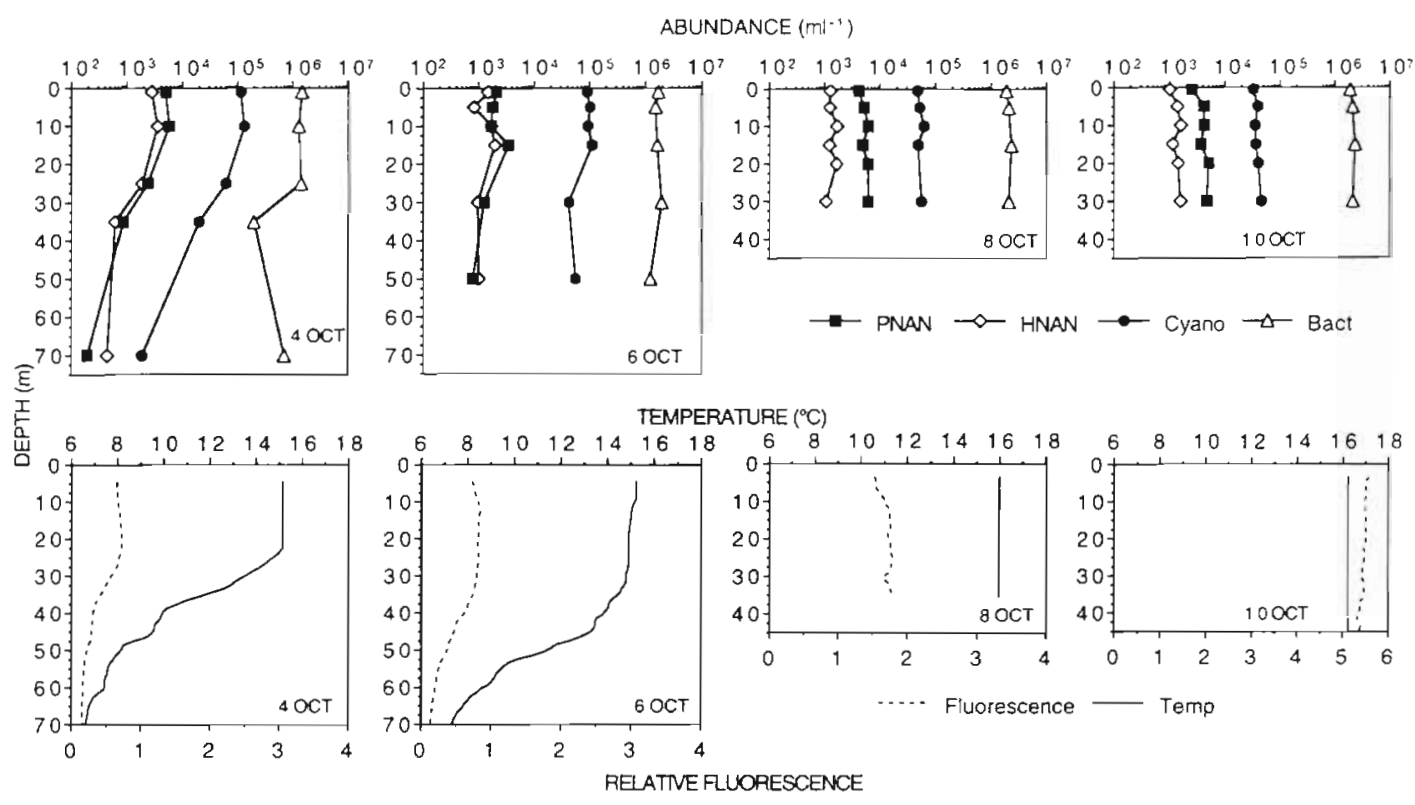

Fig. 2. Depth profiles of microorganism abundance (no. $\left.\mathrm{ml}^{-1}\right)$, temperature $\left({ }^{\circ} \mathrm{C}\right.$ ) and chlorophyll fluorescence $\left(\mu \mathrm{g} \mathrm{l}^{-1}\right)$ at stations on Georges Bank during October 1990

10 October. Abundances of cyanobacteria and PNAN from discrete samples were greater in the mixed layer at the station exhibiting stratification, but their abundances were vertically uniform at the sites without stratification (Fig. 2). Maximal abundances of cyanobacteria were approximately $1 \times 10^{5} \mathrm{ml}^{-1}$ at the former site and 4 to $6 \times 10^{5} \mathrm{ml}^{-1}$ at the latter one. Maximal abundances of PNAN were similar ( 4 to $6 \times 10^{3} \mathrm{ml}^{-1}$ ) at both sites on Georges Bank in October. The largest fluorescence values recorded in this study were observed on 10 October, but these high values were not reflected in greater abundances of pico- and nanophytoplankton on this date. Peak abundances of bacteria and HNAN were approximately $2 \times 10^{6} \mathrm{ml}^{-1}$ and 1 to $3 \times 10^{3} \mathrm{ml}^{-1}$, respectively, at both sites on Georges Bank (Fig. 2).

A well-developed seasonal thermocline was present below 55 to $65 \mathrm{~m}$ at the 2 stations in the Sargasso Sea during the October cruise (Fig. 3). Waters at these sites were isothermal above the thermocline, and a pronounced deep chlorophyll maximum (DCM) occurred at both locations at depths of 75 to $100 \mathrm{~m}$. Although small subsurface peaks of phototrophic pico- and nanoplankton occurred at each station, they were not usually concomitant with the DCM (Fig. 3). Cyanobacterial abundance varied little with depth except for a decline in the samples taken within or below the thermocline. The range of abundances of cyanobacteria at the Sargasso Sea sites in October was approximately 4 to $6 \times 10^{3} \mathrm{ml}^{-1}$, except on 22 October, when up to $8.5 \times$ $10^{3}$ cyanobacteria $\mathrm{ml}^{-1}$ were observed (Fig. 3).
Vertical profiles of PNAN in the Sargasso Sea during October were also fairly uniform, usually $\leq 5 \times 10^{2} \mathrm{ml}^{-1}$, and not strongly correlated with the presence of the DCM (Fig. 3). However, the largest PNAN abundance that we recorded at the Sargasso Sea stations during this cruise was $1.4 \times 10^{3} \mathrm{ml}^{-1}$ at the depth of the DCM on 18 October. HNAN abundances had similar trends with depth to those of PNAN at both stations, but heterotrophic forms were less abundant (Fig. 3). HNAN did not exceed $4.0 \times 10^{2}$ cells $\mathrm{ml}^{-1}$. Bacterial abundances were similar at all depths and both locales in the Sargasso Sea. Typical abundances for bacteria were 5 to $6 \times 10^{5}$ cells $\mathrm{ml}^{-1}$.

Surface water temperatures on Georges Bank during the summer cruise (late July to early August) were similar to those recorded during autumn $\left(\leq 16^{\circ} \mathrm{C}\right)$. During this cruise, a single station (water column depth $60 \mathrm{~m}$ ) was occupied on the northern edge of the bank and adjacent to the shallow station occupied during the October cruise (Fig. 1). Temperature and fluorescence profiles indicated some stratification of the water column on all sampling dates, although there was no distinct thermocline on 2 August (Fig. 4). Vertical changes in temperature and fluorescence showed similar trends, although slight, subsurface peaks of fluorescence were often present at a depth of 5 to $10 \mathrm{~m}$ (Fig. 4). Cyanobacterial and PNAN abundances had similar ranges to those observed for the assemblages during the previous October (Figs. 2 \& 4). HNAN were generally more abundant during the summer, although the maximal abundances of HNAN $\left(3.9 \times 10^{3}\right.$ cells $\left.\mathrm{ml}^{-1}\right)$ 


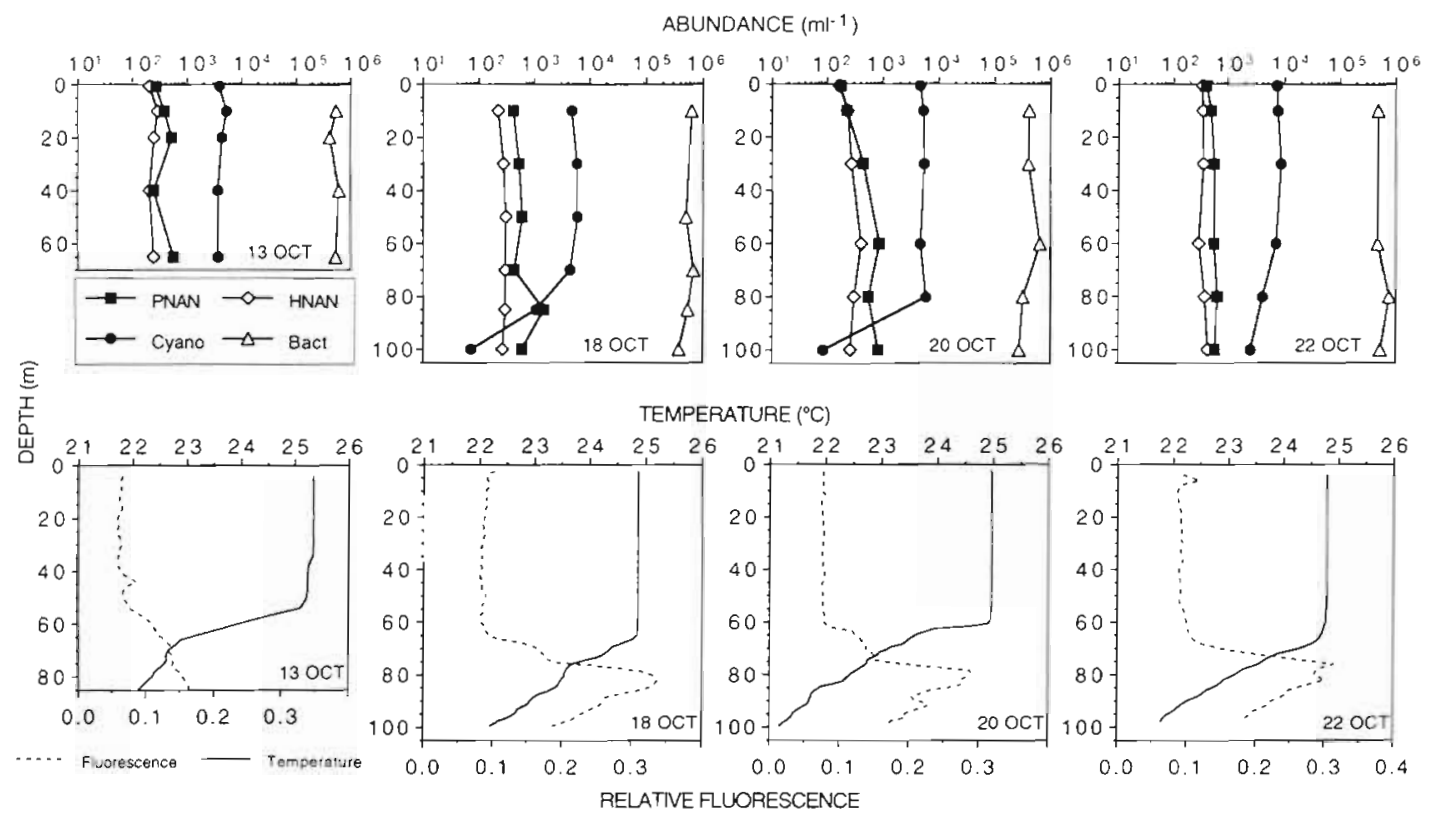

Fig. 3. Depth profiles of microorganism abundance (no. $\left.\mathrm{ml}^{-1}\right)$, temperature $\left({ }^{\circ} \mathrm{C}\right)$ and chlorophyll fluorescence $\left(\mu \mathrm{g} \mathrm{l}^{-1}\right)$ at stations in the Sargasso Sea during October 1990. Chlorophyll maximum $\left(0.34 \mu \mathrm{g} \mathrm{l}^{-1}\right)$ on 13 October was at a depth of $98 \mathrm{~m}$

were similar for the summer and autumn cruises. Bacterial abundances were not determined at each depth during the summer cruise. However, several samples taken between the surface and $15 \mathrm{~m}$ at each Georges Bank site contained 1.0 to $1.9 \times 10^{6}$ bacteria $\mathrm{ml}^{-1}$; bac-

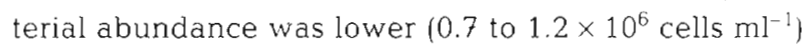
at depths of 35 to $40 \mathrm{~m}$ than near the surface.

Water column structure at the Sargasso Sea station during the August cruise did not vary appreciably. The mixed layer was warm (28 to $29^{\circ} \mathrm{C}$ ) and shallow ( $\leq 20 \mathrm{~m}$ ), and a DCM was apparent at 115 to $140 \mathrm{~m}$ (Fig. 5). Cyanobacterial abundances ranged from 2 to $7 \times 10^{3}$ cells $\mathrm{ml}^{-1}$ and were lowest in our samples from the DCM. Conversely, PNAN abundances were usually highest (up to $2 \times 10^{3}$ cells $\mathrm{ml}^{-1}$ ) at the DCM (Fig. 5). HNAN abundances were often similar to the PNAN, but the Sargasso Sea station occupied in August was the only one at which HNAN abundance

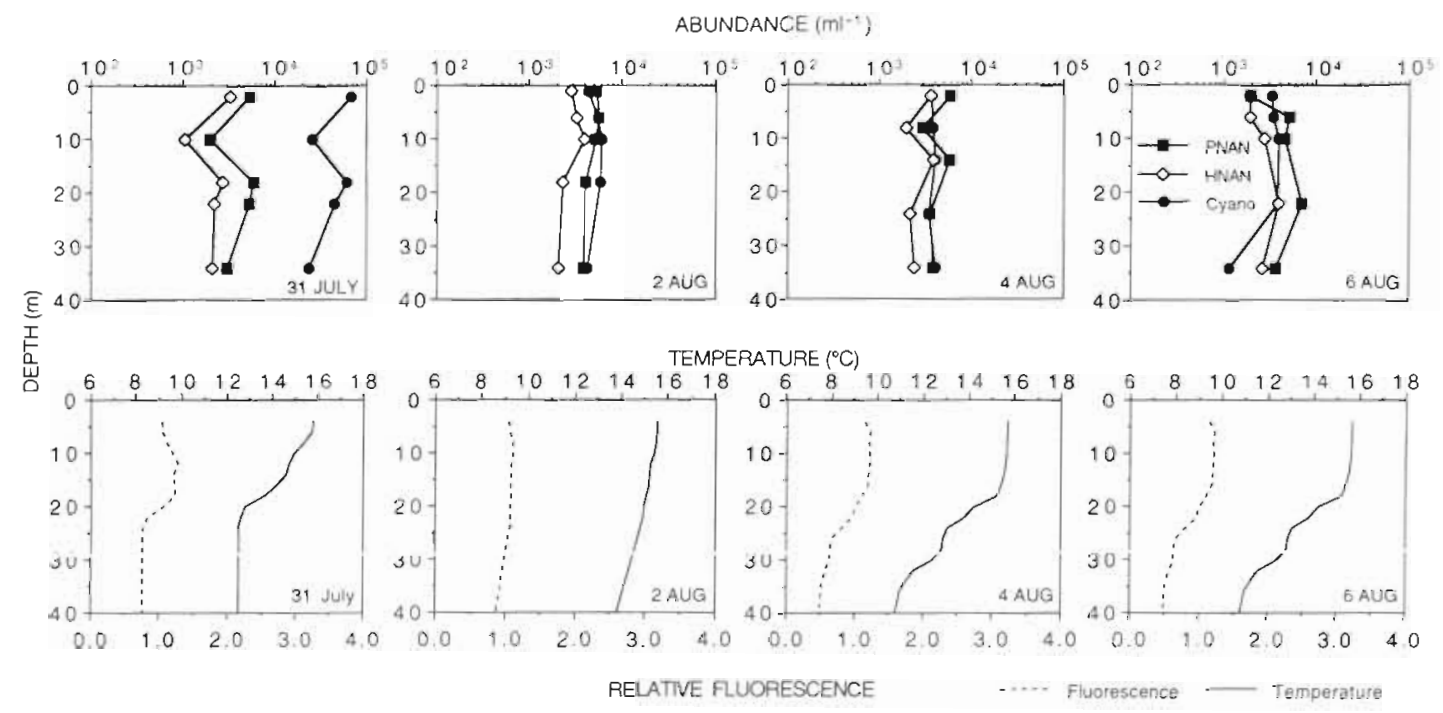

Fig. 4. Depth profiles of microorganism abundance $\left(\mathrm{no} . \mathrm{ml}^{-1}\right)$, temperature $\left({ }^{\circ} \mathrm{C}\right)$ and chlorophyll fluorescence $\left(\mu \mathrm{g} \mathrm{l}^{-1}\right)$ at stations on Georges Bank during July/Auqust 1991 


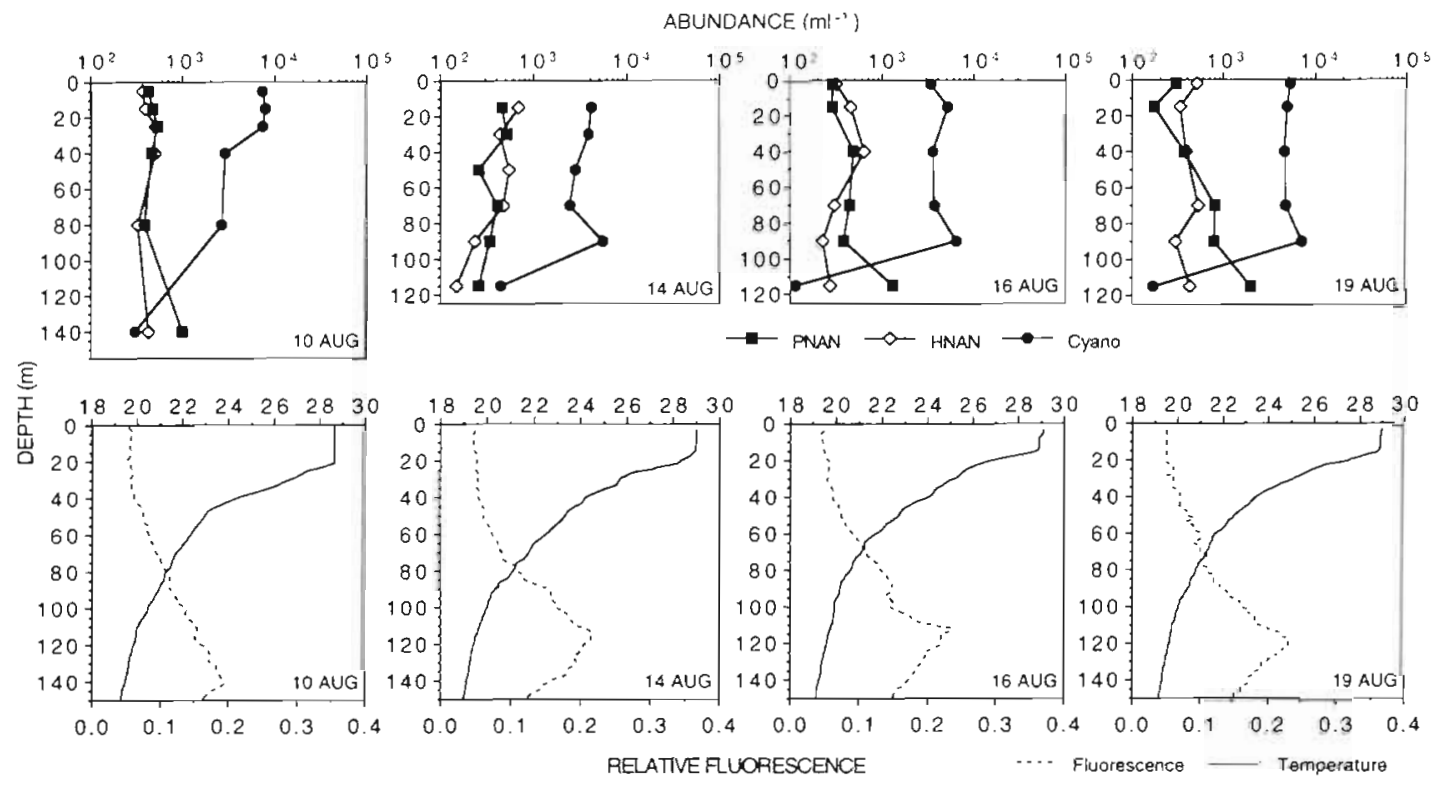

Fig. 5. Depth profiles of microorganism abundance (no. $\mathrm{ml}^{-1}$ ), temperature $\left({ }^{\circ} \mathrm{C}\right)$ and chlorophyll fluorescence $\left(\mu \mathrm{g} \mathrm{l}^{-1}\right)$ at stations in the Sargasso Sea during August 1991

frequently exceeded PNAN abundance. Bacterial abundances were determined at several depths between 15 and $120 \mathrm{~m}$ over the period of occupation and ranged from 3 to $6 \times 10^{5}$ cells $\mathrm{ml}^{-1}$.

\section{Picoplankton grazing losses and bacterial production}

The disappearance of prey surrogates indicated that predation was a significant loss factor for picoplankton in surface waters of Georges Bank and in the Sargasso Sea during this study. The absolute number of picoplankton cells removed per day was greater on Georges Bank than in the Sargasso Sea due to the greater abundances of predators and prey at the coastal site. However, specific grazing losses for picoplankton were similar across environments (Tables 1 \& 2). For example, FLA were used in 15 of 16 grazing experiments and specific grazing losses for picoplanktonic algae based on these prey surrogates averaged $>0.16 \mathrm{~d}^{-1}$ for the whole data set. Averages of the 4 experiments for each oceanic regime were very similar in both environments during each cruise; 0.14 versus $0.13 \mathrm{~d}^{-1}$ for October; 0.21 versus $0.18 \mathrm{~d}^{-1}$ for July/ August. Overall, grazing losses estimated for picophytoplankton were somewhat lower in October than in August, but there was an overlap among the results of the FLA grazing experiments conducted during each of the 4 major cruise segments (i.e. summer vs autumn, Georges Bank vs Sargasso Sea).
Predation on cyanobacteria was estimated in both environments, but only during the October cruise. For the most part, rates of disappearance of FLC were similar to the rates of disappearance of FLA. The average specific grazing loss was somewhat higher at the coastal site $\left(0.17\right.$ vs $0.11 \mathrm{~d}^{-1}$; Table 1$)$, but the ranges were similar for Georges Bank $\left(0.07\right.$ to $\left.0.26 \mathrm{~d}^{-1}\right)$ and the Sargasso Sea $\left(0.05\right.$ to $\left.0.22 \mathrm{~d}^{-1}\right)$.

The specific rates of bacterivory estimated using FLB were greatest at the Georges Bank stations during October where a rate of $0.38 \mathrm{~d}^{-1}$ was measured at 1 station (Table 1 ; average for this locale was $0.28 \mathrm{~d}^{-1}$ ). Rates of bacterial production on Georges Bank in October (range: 0.17 to $0.23 \mathrm{~d}^{-1}$, average: $0.21 \mathrm{~d}^{-1}$ ) were similar to estimates of bacterivory indicating a general balance of production and grazing (Table 1). Specific bacterial production in the Sargasso Sea during October was $<20 \%$ of that determined for Georges Bank (Table 1), but we did not determine bacterivory with FLB. We attempted to use fluorescently labeled Escherichia coli minicells (FLM) as bacterial tracers in the 4 experiments in the Sargasso Sea during October because their average size was smaller than our standard FLB. However, problems with the FLM method precluded the calculation of bacterial predation rates for the experiments in the Sargasso Sea during that cruise. High losses of FLM in the control bottles (up to $51 \%$ ) suggested that FLM fluorescence faded during the incubations or that the particles adhered to the walls of the incubation bottles. Also, clumping of FLM in the fixed samples was not dispersed by shaking or 
sonication, and this resulted in a patchy distribution on filters and high counting error. If bacterivory was equivalent to removal of FLA in the Sargasso Sea (e.g. Caron et al. 1999) then grazing equaled or exceeded bacterial production there in our October experiments.

FLB were used as tracers for bacterivory in both the coastal and oceanic environments in August (Table 2). Average grazing rates were similar on Georges Bank $\left(0.15 \mathrm{~d}^{-1}\right)$ and in the Sargasso Sea $\left(0.13 \mathrm{~d}^{-1}\right)$. In contrast to the October experiments, bacterial production on Georges Bank in summer exceeded estimates of grazing by up to a factor of $10 \times$ (Table 2). Production was more closely balanced by bacterivory in the Sargasso Sea experiments during the August cruise, but production still exceeded average grazing by a factor of $1.8 \times$.

\section{Mixotrophic nanoplankton}

Our experiments were designed in part to determine if phagotrophy by PNAN was a common occurrence in oceanic ecosystems, and if it differed markedly in magnitude between a productive coastal environment and an oligotrophic environment. Mixotrophs, defined experimentally as chloroplast-bearing nanoplankton with FLP within food vacules, were present during each experiment (Table 3). Nearly all of the MNAN and PNAN that we enumerated were $<6 \mu \mathrm{m}$ in diameter. The absolute abundances of MNAN were greater at the Georges Bank sites than for any of the Sargasso
Sea experiments. The abundance of MNAN on Georges Bank was typically several hundreds $\mathrm{ml}^{-1}$, with a maximum abundance of $2.2 \times 10^{3} \mathrm{ml}^{-1}$ on 4 October. In the Sargasso Sea MNAN did not exceed $10^{2} \mathrm{ml}^{-1}$. There was considerable spatial variation in MNAN abundance and in MNAN as a proportion of either total PNAN or total phagotrophic nanoplankton. This variability was most obvious for the Georges Bank stations in October where there appeared to be a small 'bloom' of mixotrophic algae. Even if this 'bloom' sample is excluded, variation in the number of MNAN within any of the 4 general sampling areas/times was as great as the differences between seasons or between regions (ANOVA, p > 0.05).

In contrast to MNAN abundances which were always greater during Georges Bank experiments, the proportion of MNAN was greater for some experiments in the Sargasso Sea than at some sites near Georges Bank (Table 3). The largest percentages of PNAN that were mixotrophic at the coastal ocean site and Sargasso Sea sites were 38 and $18 \%$, respectively. On average, MNAN comprised 10 to $20 \%$ of the PNAN at all sites. MNAN also were a substantial proportion of total phagotrophic nanoplankton. MNAN constituted the largest percentage of phagotrophic nanoplankton during the mixotroph 'bloom' at Georges Bank in October (39\%). MNAN as a percentage of both the PNAN and total phagotrophic nanoflagellate populations tended to be lower in the summer than in autumn.

Table 3. Abundance of total phototrophic nanoplankton (PNAN) including mixotrophs, total heterotrophic nanoplankton (HNAN), mixotrophic nanoplankton (MNAN) and MNAN as a percentage of PNAN and total phagotrophs (Phago = HNAN + MNAN in samples from the mixed surface layer. MNAN were defined as chloroplast-bearing cells that also contained fluorescent prey following incubations with fluorescent tracers for $24 \mathrm{~h}$ (Georges Bank) or $36 \mathrm{~h}$ (Sargasso Sea). FLB = fluorescently labeled bacteria; FLM = fluorescently labeled minicells (see 'Methods' section)

\begin{tabular}{|c|c|c|c|c|c|c|c|c|}
\hline & \multirow[t]{2}{*}{ Date } & \multirow{2}{*}{$\begin{array}{l}\text { Tracer } \\
\text { type }\end{array}$} & \multirow{2}{*}{$\begin{array}{l}\text { Depth } \\
\text { (m) }\end{array}$} & \multirow{2}{*}{$\begin{array}{l}\text { PNAN } \\
\left(\mathrm{ml}^{-1}\right)\end{array}$} & \multirow{2}{*}{$\begin{array}{l}\text { HNAN } \\
\left(\mathrm{ml}^{-1}\right)\end{array}$} & \multirow{2}{*}{$\begin{array}{l}\text { MNAN } \\
\left(\mathrm{ml}^{-}\right)\end{array}$} & \multicolumn{2}{|c|}{$\%$ mixotrophic } \\
\hline & & & & & & & PNAN & Phago \\
\hline \multirow[t]{4}{*}{ Georges Bank } & 4 Oct 1990 & FLB & 10 & 5760 & 3530 & 2210 & 38 & 39 \\
\hline & 6 Oct 1990 & FLB & 10 & 1670 & 1690 & 420 & 25 & 20 \\
\hline & 8 Oct 1990 & FLB & 5 & 5150 & 1240 & 100 & $<2$ & 7 \\
\hline & 10 Oct 1990 & FLB & 5 & 4140 & 1370 & 170 & 4 & 11 \\
\hline \multirow[t]{4}{*}{ Sargasso Sea } & 13 Oct 1990 & FLM & 20 & 520 & 245 & 95 & 18 & 28 \\
\hline & 18 Oct 1990 & FLM & 10 & 410 & 220 & 60 & 15 & 21 \\
\hline & 20 Oct 1990 & FLM & 10 & 225 & 230 & 30 & 1.3 & 12 \\
\hline & 22 Oct 1990 & FLM & 10 & 470 & 330 & 55 & 12 & 14 \\
\hline \multirow[t]{4}{*}{ Georges Bank } & 31 Jul 1991 & FLB & 2 & 5280 & 3230 & 370 & 7 & 10 \\
\hline & 2 Aug 1941 & FLB & 2 & 5320 & 2840 & 380 & 7 & 12 \\
\hline & 4 Aug 1991 & FLB & 2 & 5950 & 3650 & 540 & 9 & 13 \\
\hline & 6.Aug 1991 & FLB & 2 & 1940 & 1940 & 580 & 30 & 23 \\
\hline \multirow[t]{4}{*}{ Sargasso Sea } & 10 Aug 1991 & FLB & 15 & 470 & 390 & 70 & 15 & 15 \\
\hline & 14. Aug 1991 & FLB & 15 & 460 & 680 & 25 & 5 & 4 \\
\hline & 16 Aug 1991 & FLB & 15 & 285 & 450 & 20 & 7 & 4 \\
\hline & 19 Aug 1991 & FLBB & 15 & 170 & 330 & 30 & 18 & 8 \\
\hline
\end{tabular}




\section{DISCUSSION}

\section{Microbial abundance on Georges Bank and in the Sargasso Sea}

Overall, the abundances of pico- and nanoplankton that we observed for Georges Bank and the Sargasso Sea were typical of those reported for coastal and oligotrophic systems, respectively (Table 4). On Georges Bank, average densities of nanoplankton for October and July/August, respectively, were $4.1 \times 10^{3}$ and $4.7 \times$ $10^{3} \mathrm{ml}^{-1}$ for PNAN, and $1.6 \times 10^{3}$ and $2.7 \times 10^{3} \mathrm{ml}^{-1}$ for HNAN. Average cyanobacterial abundances varied by a factor $>4$ across seasons $\left(1.59 \times 10^{4}\right.$ and $6.8 \times$ $10^{4} \mathrm{ml}^{-1} \mathrm{j}$, with higher abundances observed during October. If the data from 31 July are excluded, the average cyanobacterial abundance for the summer sampling period was further reduced to $4.29 \times 10^{3} \mathrm{ml}^{-1}$, only $6 \%$ of the October average. The differences in
Synechococcus densities that we observed probably were not a consequence of temperature. Although a positive correlation between Synechococcus abundance and temperature has been noted (Murphy \& Haugen 1985), surface water temperatures at this site were comparable during both seasons $\left(15\right.$ to $16^{\circ} \mathrm{C}_{i}$ Figs. 2 \& 4). Similarly, predation rates were not dramatically different during the 2 study periods (Tables 1 \& 2). Presumably, differences in cyanobacterial growth rate as a consequence of light regime, water column structure, nutrient limitation, or some combination of these were the cause for differences in the standing crop of cyanobacteria on Georges Bank during the 2 seasons.

In the surface waters of the Sargasso Sea, phototrophic pico- and nanoplankton abundances were similar during the autumn and summer cruises. The average abundances of cyanobacteria in surface waters were $4.8 \times 10^{3}$ and $5.6 \times 10^{3} \mathrm{ml}^{-1}$ in the autumn

Table 4. Minimal and maximal abundances of picoplankton and nanoplankton in surface waters (usually $\leq 20 \mathrm{~m}$ ) of coastal and open ocean systems. Maximal and minimal abundances that sometimes occurred in deep water on a given date (e.g. Figs. 2 to 5 ) are not reported here. In our samples, only cyanobacteria at depths $\geq 80 \mathrm{~m}$ tended to differ substantially from the given ranges

\begin{tabular}{|c|c|c|c|c|c|c|c|c|c|c|}
\hline \multirow[t]{2}{*}{ Environment } & \multicolumn{2}{|c|}{$\begin{array}{c}\text { Bacteria } \\
\left(\times 10^{6} \mathrm{ml}^{-1}\right)\end{array}$} & \multicolumn{2}{|c|}{$\begin{array}{l}\text { Cyanobacteria } \\
\qquad\left(\times 10^{4} \mathrm{ml}^{-1}\right)\end{array}$} & \multicolumn{2}{|c|}{$\begin{array}{c}\text { PNAN } \\
\left(\times 10^{3} \mathrm{ml}^{-1}\right)\end{array}$} & \multicolumn{2}{|c|}{$\begin{array}{c}\text { HNAN } \\
\left(\times 10^{3} \mathrm{ml}^{-1}\right)\end{array}$} & \multirow[t]{2}{*}{$\mathrm{n}$} & \multirow[t]{2}{*}{ Source } \\
\hline & & & & Max. & & Max. & & Max. & & \\
\hline \multicolumn{11}{|l|}{ Coastal } \\
\hline Chesapeake Bay plume & 1.1 & 9.1 & - & - & - & - & 0.8 & 4.4 & 16 & McManus \& Fuhrman (1988) \\
\hline Georgia Coast & 2.0 & 11.0 & - & - & 0.3 & 22 & 0.3 & 3.2 & 28 & Sherr et al. (1984) \\
\hline Vinyard Sound & 2.2 & 2.4 & 0.6 & 4.4 & - & - & 1.3 & 1.9 & 4 & Caron et al. (1991) \\
\hline Bering/Chukchi Seas & $<0.1$ & 1.7 & $<0.1$ & 1.0 & - & - & 0.1 & 2.6 & 145 & Andersen (1988) \\
\hline Continental Shelf, Atlantic & - & 1.3 & - & - & - & 2.9 & - & 3.1 & a & Davis et al. (1985) \\
\hline Continental Shelf, Atlantic & 1.0 & 2.0 & 1.9 & 3.0 & 1.3 & 3.0 & 0.4 & 2.6 & 7 & Caron et al. (1986) \\
\hline Georges Bank & 0.2 & 1.5 & - & - & - & - & 0.2 & 3.1 & - & Hobbie et al. (1987) \\
\hline Georges Bank & 1.1 & 2.4 & 0.3 & 13 & 1.7 & 6.0 & 0.8 & 3.9 & 25 & This study \\
\hline \multicolumn{11}{|l|}{ Open Ocean } \\
\hline West Pacific, subarctic & - & - & - & - & 0.1 & 2.5 & 0.1 & 0.6 & 22 & Suzuki et al. (1998) \\
\hline West Pacific, subtropic & - & - & - & - & 0.6 & 2.8 & 0.2 & 0.5 & 12 & Suzuki et al. (1998) \\
\hline North Pacific, subtropic & 0.2 & 0.6 & 0.02 & 0.1 & 0.4 & 1.4 & - & - & & Campbell \& Vaulot (1993) \\
\hline South Pacific, tropical & - & - & $<0.1$ & 0.8 & - & - & - & - & - & Charpy \& Blanchot (1998) \\
\hline Mediterranean Sea & $<0.1$ & 2.4 & - & - & - & - & $<0.1$ & 0.8 & - & Zohary \& Robarts (1992) \\
\hline Mediterranean Sea & 0.2 & 0.7 & 0.2 & 13.0 & $0.3^{b}$ & $5.2^{b}$ & 0.2 & 0.8 & 41 & $\begin{array}{l}\text { Ferrier-Pagès \& } \\
\text { Rassoulzadegan (1994) }\end{array}$ \\
\hline Gulf Stream & 0.1 & 1.3 & $<0.1$ & 5.5 & $<0.1$ & 1.6 & 0.2 & 1.8 & 18 & Caron et al. (1986) \\
\hline Continental Slope, Atlantic & - & 0.8 & - & 0.3 & - & 0.7 & - & 0.7 & a & Davis et al. (1985) \\
\hline Continental Slope, Atlantic & 0.5 & 1.1 & 0.8 & 1.0 & 1.0 & 3.0 & 0.8 & 3.2 & 5 & Caron et al (1986) \\
\hline North Atlantic Ocean & - & 0.4 & - & 0.1 & - & 0.8 & - & 0.7 & a & Davis et al. (1985) \\
\hline North Atlantic Ocean & - & - & 2.2 & 4.6 & 7.0 & 10.3 & 3.6 & 6.6 & c & Stoecker et al. (1994) \\
\hline North Atlantic Ocean & 0.3 & 0.6 & $0.4^{\mathrm{b}}$ & $4.4^{\mathrm{b}}$ & - & - & 0.6 & 1.2 & 6 & Weisse \& Scheffel-Möser (1991) \\
\hline North Atlantic Ocean & 0.3 & 2.2 & $<1.0$ & 8.0 & - & - & - & - & - & Buck et al. (1996) \\
\hline Sargasso Sea & - & - & 0.6 & 8.0 & 1.0 & 12.0 & - & - & d & Olson et al. (1990) \\
\hline Sargasso Sea & 0.2 & 0.3 & 0.8 & 1.7 & - & - & - & - & 8 & Glover et al. (1988) \\
\hline Sargasso Sea & 1.1 & 1.2 & 1.0 & 6.5 & 0.2 & 1.1 & 0.4 & 0.8 & 7 & Fuhrman et al. (1989) \\
\hline Sargasso Sea & 0.3 & 0.9 & 0.3 & 2.6 & 0.1 & 1.6 & 0.3 & 0.6 & 14 & Caron et al. (1995) \\
\hline Sargasso Sea & 0.2 & 0.6 & 0.3 & 0.8 & 0.2 & 0.5 & 0.2 & 0.7 & 14 & This study \\
\hline
\end{tabular}


and summer, respectively, while PNAN averaged $3.7 \times$ $10^{2} \mathrm{ml}^{-1}$ for both cruises (Table 3 ) These values are typical of highly oligotrophic oceanic waters, although much higher abundances have been reported from more productive oceanic ecosystems including the tropical Pacific Ocean (Li et al. 1983, and more productive areas of the Atlantic Ocean (Table 4).

PNAN often occurred at greater abundances within the DCM than at the surface in the Sargasso Sea (Figs. $3 \& 5$ ). Cyanobacteria exhibited slight subsurface maxima, but unlike PNAN, their abundances tended to be lower within and below the DCM relative to the mid-euphotic zone. This trend was true for both the October cruise, when the DCM was found at approximately $85 \mathrm{~m}$, and the August cruise, when the DCM was located at a depth of approximately $115 \mathrm{~m}$. Our observations of increased PNAN abundances and decreased cyanobacterial abundances in the lower euphotic zone are consistent with other studies in the Sargasso Sea, central North Pacific Ocean, and in the richer waters of the Arabian Sea and coastal Peru (Waterbury et al. 1979, Glover et al. 1988, Olson et al 1990, Campbell \& Vaulet 1993, Arenovski et al. 1995). These differences in depth distribution of the PNAN and Synechococcus have been attributed to differences in photosynthetic pigment composition of the groups that result in changes in their relative light absorption efficiencies and consequently growth at various depths (e.g. Olson et al. 1990).

Well-developed deep maxima of chlorophyll fluorescence that occurred in the absence of concomitant increases in the abundance of PNAN and cyanobacteria (Figs. $3 \& 5$ ) were likely due to increases in the concentration of photosynthetic pigment per cell, as well as the exclusion of some phototrophic microorganisms from our analyses. The former phenomenon (photoadaptation at low light) has been noted for photosynthetic eukaryotes, prochlorophytes and Synechococcus (Olson et al. 1990, Li et al. 1992). In addition, our microscopical analyses did not include microplanktonic and larger algae (i.e. $>20 \mu \mathrm{m}$ ), or account for the presence of prochlorophytes. The prochlorophyte Prochlorococcus has been shown to contribute $>35 \%$ of chlorophyll fluorescence in the deep euphotic zones of some oceanic ecosystems (Olson et al. 1990, Chavez et al. 1991, Campbell et al. 1994), and presumably constituted a significant fraction of the DCM in the present study.

Abundances of heterotrophic bacteria and HNAN in the Sargasso Sca wore 1 ordor of magnitude loss than those on Georges Bank. The heterotrophs, like the phototrophic plankton, fit with abundance patterns reported previously for oligotrophic ecosystems (Table 4). HNAN densities in surface waters were typically 3.0 to $5.0 \times 10^{2} \mathrm{ml}^{-1}$ and bacteria were 2.0 to $5.0 \times$ $10^{5} \mathrm{ml}^{-1}$ during both cruises. Bacterial abundances in samples collected near or at the DCM in the Sargasso Sea were probably overestimated in the present study because Prochlorococcus were only weakly fluorescent and could not be distinguished from bacteria in our epifluorescence microscopical procedure (Campbell et al. 1994). Based on previous reports of Prochlorococcus in the Sargasso Sea (Olson et al. 1990, Goericke \& Welschmeyer 1993), we estimate that bacterial abundances at these sites and depths were overestimated by $\leq 10 \%$.

\section{Community grazing impact}

The mortality of auto- and heterotrophic picoplankton is frequently linked to predation by protozoa (reviewed in Sanders et al. 1992, Sherr \& Sherr 1994) and we attribute a major portion of the picoplankton mortality in our experiments to protists. Every type of FLP used in our experiments was ingested by both HNAN and MNAN, and grazing was detected in every experiment. Rates of removal of FLB on Georges Bank during the October cruise were greater than rates of removal of FLC or FLA, but differences at other times and places were not dramatic (Tables 1 \& 2)

Although other organisms can ingest cells $<2 \mu \mathrm{m}$ in size, numerous studies have identified nanoflagellates as the major predators of picoplankton le.g. Weisse 1989, Sherr \& Sherr 1991, 1994, Sanders et al. 1992, Caron et al. 1999). As a check on the assumption that nanoplankton were responsible for most of the grazing in our experiments, we calculated bacterivory using clearance rates from the literature and our abundance determinations. Grazing impacts were determined using clearance rates of 4.2 and $1.4 \mathrm{nl}$ flagellate ${ }^{-1} \mathrm{~h}^{-1}$ for coastal heterotrophs and mixotrophs, respectively (Havskum \& Riemann 1996). Rates of 15 nl HNAN ${ }^{-1} \mathrm{~h}^{-1}$ (average from Weisse \& Scheffel-Möser 1991) and $2.6 \mathrm{nl}$ mixotroph ${ }^{-1} \mathrm{~h}^{-1}$ (Safi \& Hall 1999) were considered representative for oceanic species. Calculations for 16 of 19 incubations where grazing on picoplankton was determined using FLB or FLC indicated that nanoflagellates grazing at these moderate rates could account for all of the picoplankton removal. In the remaining incubations, the calculations indicated that approximately $50 \%$ of the measured predation was accounted for by nanoflagellates if they grazed at the above rates. Nanoflagellates grazing at bighor rates could account for this discrepuncy. Much higher clearance rates have been noted for flagellate grazers in coastal 14.6 to $17 \mathrm{nl}$ flagellate ${ }^{-1} \mathrm{~h}-1$, Caron et al. 1991) and oceanic environments (up to $94 \mathrm{nl}$ flagellate $\mathrm{h}^{-1}$, Weisse 1989). Additionally, the number of MNAN that we identified is probably a minimum (see below). Conversely, other predators such as ciliates 
may have been responsible for the removal of some FLP (Sherr et al. 1989). It is most likely, however, that nanoplankton were major grazers in all of our experiments.

Our estimates for community predation on bacteria and cyanobacteria are also within the ranges reported from coastal and oceanic ecosystems. However, the maximum specific grazing rates that we determined are in the lower half of the ranges (Table 5), and some rates measured by other researchers in oligotrophic sites exceeded our estimates on the Georges Bank. Our results from the Sargasso Sea concur with the few estimates of picoplankton grazing made there. For example, the maximum specific rate of bacterivory calculated by Fuhrman et al. (1989) was identical to that which we determined experimentally for the Sargasso Sea. Caron et al. (1999) determined grazing rates on picoplankton as high as $0.61 \mathrm{~d}^{-1}$ in the Sargasso Sea south of Bermuda (Table 5); averages for surface waters were 0.22 and $0.32 \mathrm{~d}^{-1}$ during their experiments in March/April and August, respectively. These average grazing rates were greater than what we determined, but bacterial production was also higher at those sites (Caron et al. 1999). Notably, the grazing rates that we determined using FLA in the Sargasso Sea in August (Table 2) were within the 95\% confidence intervals of grazing on cyanobacteria determined by the dilution method in 3 experiments at the same site (Lessard \& Murrell 1998, Table 5).

\section{Grazing rate determinations}

The comparison of grazing and production rates that follows assumes that our measurements accurately reflected the consumption and growth that occurred during the study. The potential sources of error are discussed in detail in Caron et al. (1999), but we will briefly address the important ones here. When using substitute prey in plankton studies there is always a

Table 5. Specific grazing impact on picoplankton determined by various methods. Rates were sometimes calculated from hourly rates with the assumption that there were no diel changes. PPE = photosynthetic picoeukaryotes

\begin{tabular}{|c|c|c|c|c|c|c|c|c|c|}
\hline \multirow{2}{*}{$\begin{array}{l}\text { Environment } \\
\text { Coastal }\end{array}$} & $\begin{array}{l}\text { Bact } \\
\text { Min. }\end{array}$ & $\begin{array}{l}\text { Specific } \\
\text { teria } \\
\text { Max. }\end{array}$ & $\begin{array}{c}\text { c Grazir } \\
\text { Cyanok } \\
\text { Min. }\end{array}$ & $\begin{array}{l}\text { ng Rates } \\
\text { oacteria } \\
\text { Max. }\end{array}$ & $\begin{array}{c}\mathrm{s}\left(\mathrm{d}^{-1}\right) \\
\mathrm{PF} \\
\mathrm{Min} .\end{array}$ & Max. & Method & $\mathrm{n}$ & Source \\
\hline & & & & & & & & & \\
\hline $\begin{array}{l}\text { Estuary/coastal, } \\
\text { NE Atlantic }\end{array}$ & 0.10 & 1.2 & - & - & - & - & Size fractionation & 20 & Wright \& Coffin (1984) \\
\hline Long Island, NY & 0.18 & 2.6 & - & - & - & - & Inhibitors & 12 & Fuhrman \& McManus (1984) \\
\hline Chesapeake Bay plume & 0.01 & 0.19 & - & - & - & - & Tracer uptake & 17 & McManus \& Fuhrman (1988) \\
\hline Bothnian/North Seas & 0.22 & 0.71 & - & - & - & - & Minicell recapture & - & Wikner et al. (1990) \\
\hline Finnish Bay & - & 1.19 & - & - & - & - & Minicell recapture & - & Wikner et al. (1990) \\
\hline Long Island Sound & - & - & - & 0.22 & - & - & Dilution/inhibitors & 1 & Campbell \& Carpenter (1986) \\
\hline Gulf of Maine & - & - & 0.61 & 0.83 & - & - & Dilution/inhibitors & 3 & Campbell \& Carpenter (1986) \\
\hline Vineyard Sound, MA & 0.01 & 0.75 & 0.30 & 0.47 & - & - & Inhibitors & $4-5$ & Caron et al. (1991) \\
\hline Halifax, NS & - & - & - & - & - & $0.22^{b}$ & Dilution & & Gifford (1988) \\
\hline Georges Bank & 0.12 & 0.38 & 0.07 & 0.26 & 0.08 & 0.24 & Loss of tracers & $4-8$ & This study \\
\hline Open Ocean & & & & & & & & & \\
\hline Equatorial Pacific & $0.51^{\mathrm{A}}$ & $1.0^{\mathrm{a}}$ & 0.52 & 1.1 & 0.39 & 0.77 & Dilution & 20 & Landry et al. (1995) \\
\hline Equatorial Pacific & $0.52^{\circ}$ & $0.80^{\mathrm{a}}$ & 0.55 & 0.88 & 0.54 & 0.75 & Relative grazing & 20 & Landry et al. (1995) \\
\hline Equatorial Pacific & - & $0.78^{\mathrm{a}, \mathrm{c}}$ & - & $0.82^{\mathrm{C}}$ & - & - & Dilution & 4 & Latasa et al (1997) \\
\hline Arabian Sea & - & $0.59^{\mathrm{a}}$ & 0.26 & 0.73 & 0.18 & 0.67 & Dilution $<200 \mu \mathrm{m}$ only & & Reckermann \& Veldhuis (1997) \\
\hline Red Sea/Gulf of Aden & - & $0.80^{a}$ & 0.06 & 0.38 & 0.60 & 1.8 & Dilution $<200 \mu \mathrm{m}$ only & - & Reckermann \& Veldhuis (1997) \\
\hline Red Sea/Gulf of Aden & 0.29 & 1.9 & - & - & - & - & Inhibitors & 16 & Weisse (1989) \\
\hline Indian Ocean & - & - & 0.7 & 1.0 & - & - & & - & Burkhill et al. (1993) \\
\hline Mediterranean Sea & - & 0.56 & - & - & - & - & Minicell recapture & 1 & Wikner et al. (1990) \\
\hline Mediterranean Sea & 0.57 & 0.66 & - & 0.48 & - & - & $\begin{array}{l}\text { Minicell recapture/ } \\
\text { Population decrease }\end{array}$ & $1-6$ & Hagström et al. (1988) \\
\hline $\begin{array}{l}\text { Warm Core Ring, } \\
\text { Atlantic }\end{array}$ & - & - & $-{ }^{d}$ & 0.35 & - & - & Dilution/inhibitor & 1 & Campbell \& Carpenter (1986) \\
\hline Sargasso Sea & - & - & $--^{\mathrm{d}}$ & 0.33 & - & - & Dilution & 4 & Lessard \& Murrell (1998) \\
\hline Sargasso Sea & 0.03 & 0.16 & - & - & - & - & Biomass $\times \operatorname{cscr}^{e}$ & - & Fuhrman et al. (1989) \\
\hline Sargasso Sea & $-{ }^{d}$ & $0.61^{f}$ & - & - & - & - & Loss of tracers & - & Caron et al. (1999) \\
\hline Sargasso Sea & 0.11 & 0.16 & 0.05 & 0.22 & 0.10 & 0.20 & Loss of tracers & $4-8$ & This study \\
\hline
\end{tabular}


possibility of feeding selectivity for or against the surrogates (relative to natural prey) based on size, motility or taste discrimination. Size discrimination can be either positive or negative (i.e. large cells may be consumed more or less readily than smaller ones); however, larger cells ( 1 to $2 \mu \mathrm{m}$ ) are usually grazed at higher rates than smaller $(0.5 \mu \mathrm{m})$ prey (e.g. Safi \& Hall 1999). In practice, motility and taste discrimination probably result in selection of natural bacteria more often than FLB (Monger \& Landry 1992), and this may balance the size selectivity for larger FLB. In contrast, the FLC were the same size as natural cyanobacteria and Synechococcus is not mobile like many marine bacteria, so these factors probably had little impact on our estimates of grazing on cyanobacteria. However, the effects of 'taste' or cell surface properties of FLC on our grazing rate determinations are unknown. Given these considerations and the overall moderate specific grazing rates relative to other studies (Table 5), predation rates obtained in this study using FLP are minimal estimates.

\section{Comparing bacterial production and predation}

Bacterial production is often offset by grazing losses in coastal ecosystems and in the oligotrophic ocean (Wright \& Coffin 1984, Hagström et al. 1988, McManus \& Fuhrman 1988, Sherr et al. 1989, Weisse 1989, Wikner et al. 1990, Marrasé et al. 1992, KuuppoLeinikki et al. 1994, del Giorgio et al. 1996, Caron et al. 1999). A balance between productivity and grazing losses also has been noted in studies of photosynthetic picoplankton (Campbell \& Carpenter 1986, FerrierPagès \& Rassoulzadegan 1994, Latasa et al. 1997. Reckermann \& Veldhuis 1997)

In the present study, bacterivory equaled or exceeded bacterial production at Georges Bank during the October cruise (Table 1). The grazing rate on FLC and the calculated grazing from abundance and literature rates (see above) indicate that grazing also balanced the low productivity of bacteria in the Sargasso Sea during October (Table 1). Bacterial production was approximately balanced by grazing in the Sargasso Sea during the August cruise (Table 2), but the ratio of production:grazing ranged from 1.3 to 2.2 for the 4 experiments. At another site in the Sarujasso Sea, bacterial production was noted to be balanced by grazing in spring, but to ovceed it by nearly $2 x$ in August (Caron et al. 1999). Further research is required to determine if this apparent increase in bacterial production relative to grazing during August is a consistent feature of the system. In contrast to most of our experiments, bacterial production greatly exceeded bacterivory on Georges Bank during the July/August cruise (Table 2); production was nearly $8 \times$ greater than grazing mortality at that time. The average bacterial production on Georges Bank was greater in August than in October (Tables $1 \& 2$ ), but the abundance of flagellates was similar during the 2 cruises (Table 3). Predation on nanoflagellates may have affected the balance between grazing and bacterial production by uncoupling the flagellate-bacteria trophic link. This scenario has been observed in coastal systems and modeling suggests it may be most common in more eutrophic systems (Dolan \& Gallegos 1991, Sanders et al. 1992).

\section{Mixotrophy}

Mixotrophy is the combination of autotrophic and heterotrophic nutrition in a single organism. Among the protists, it includes interactions ranging from phototrophs acquiring dissolved and/or particulate organic matter, to chloroplast-enslavement, to the functional mixotrophy of symbiont-bearing foraminifera (Sanders 1991, Stoecker 1998). We limited our observations to the occurrence of phagotrophic phytoflagellates in the mixed surface layer. Our results indicate that phagotrophy by photosynthetic flagellates is a widespread, albeit highly variable, phenomenon.

MNAN were identified at all of the stations that we sampled in the Sargasso Sea and on Georges Bank. The abundances reported here must be considered minimal estimates for several reasons. For example, we observed only nanoplankton-sized mixotrophs (2 to $20 \mu \mathrm{m})$, but may have missed larger mixotrophic flagellates due to the small size of the tracer particles that we employed. Larger mixotrophic flagellates, especially dinoflagellates, tend to ingest larger food items. Mixotrophic dinoflagellates in a Norwegian fjord ingested 2 to $5 \mu \mathrm{m}$ FLA, but not $1 \mu \mathrm{m}$ FLB, while other mixotrophic dinoflagellates ingested ciliates (Bockstahler \& Coats 1993, Jacobson \& Anderson 1996. Havskum \& Hansen 1997). In addition, individual physiological condition could have affected our abundance estimates of phagotrophic algae. Any factor that inhibits ingestion rate will cause an underestimate of potential mixotrophs, but even in laboratory experiments not all individuals (either MNAN or HNAN) will contain ingested particles. Unlike HNAN which are usually identified directly using epifluorescence microscopy, the only method available for establishing mixotrophic bchavior in nitural samples is to demonstirate the ingestion of food particles or fluorescent tracers. Mixotrophs thus could be underestimated if phagotrophic behavior ceased during cell division (Boraas et al. 1992), if there were selectivity against the tracer particles, or if nutrient concentration or light intensity reduces feeding. 
The acquisition of nitrogen and phosphorus from particulate food when concentrations of dissolved nutrients are low is one potential advantage of mixotrophy (Sanders 1991, Nygaard \& Tobiesen 1993). When dissolved nutrients are replete, phagotrophy may be reduced or cease (Nygaard \& Tobiesen 1993, Arenovski et al. 1995, Havskum \& Riemann 1996). Havskum \& Riemann (1996) noted high mixotroph abundance in the surface waters at a coastal site. However, the density of mixotrophs decreased below the pycnocline. The diminished role of mixotrophy in the bottom waters was attributed to high nutrient concentrations there relative to surface waters (Havskum \& Riemann 1996). Decreasing phagotrophic activity or abundance of mixotrophic algae with increasing depth was also attributed to greater availability of dissolved nutrients at depth by Nygaard \& Tobiesen (1993) in coastal waters and by Arenovski et al. (1995) in the Sargasso Sea. At oceanic sites where $>50 \%$ of the PNAN were mixotrophs in the near-surface waters, they were barely detectable in the DCM (Arenovski et al. 1995).

We anticipated that the proportion of mixotrophic algae would be low on Georges Bank where tidal mixing maintains much higher concentrations of dissolved inorganic nutrients compared to the oligotrophic Sargasso Sea. However, the absolute abundance of mixotrophs was always greater at our coastal site, and the proportions of photosynthetic nanoplankton that were mixotrophic in coastal and oligotrophic waters had similar ranges. In coastal waters 2 to $38 \%$ were mixotrophic, while in the Sargasso Sea 5 to $29 \%$ of the phototrophs were mixotrophs (Table 3). It is noteworthy that acquisition of major nutrients is only one of several possible inducements of phagotrophic behavior among algal species (Boraas et al. 1988, Caron et al. 1990, Sanders et al. 1990, Sanders 1991, Caron et al. 1993, Rothaupt 1996). Hall et al. (1993) also measured high rates of bacterivory by phytoflagellates in coastal waters during an upwelling event when nitrogen and phosphorus concentrations were high. The high proportions of mixotrophs found in areas of upwelling and high tidal mixing where nutrient limitation of phytoplankton growth is not expected support the idea that factors besides nutrient concentration may alter mixotroph abundance.

The highly variable abundances that we observed seemed typical of mixotrophy in marine ecosystems. MNAN were reported to comprise $<5$ to $53 \%$ of the phototrophic nanoplankton in surface waters of the Sargasso Sea (Arenovski et al. 1995). Safi \& Hall (1999) found that almost all identifiable species of phototrophic nanophytoflagellates in the Pacific Ocean east of New Zealand's South Island were capable of ingesting FLP. In the Bay of Aarhus, mixotrophs accounted for 9 to $49 \%$ of the phototrophic biomass (Havskum \& Riemann 1996). The few available data on the grazing impact of phagotrophic phytoflagellates indicate mixotroph assemblages can constitute a significant fraction of picoplankton mortality. Experimental studies have demonstrated that mixotrophs contributed up to $60 \%$ of the bacterivory and $57 \%$ of the herbivory on picophytoplankton and small $(<5 \mu \mathrm{m}$ ) nanophytoplankton (Hall et al. 1993, Nygaard \& Tobiesen 1993, Havskum \& Riemann 1996, Havskum \& Hansen 1997, Safi \& Hall 1999). However, mixotroph grazing impact, linked to their abundance, also tended to be highly variable in space and time. Uncertainty in the factors inducing phagotrophy in different algal species leads to difficulty in predicting where and when mixotrophy will be an important ecosystem process.

The sometimes large proportions of MNAN noted in recent studies have important implications for algal nutrition, nutrient dynamics and food web interactions in planktonic ecosystems. The potential predation impact of mixotrophs in these environments may be substantial. Laboratory and in situ feeding rates determined for several photosynthetic marine taxa are of the same magnitude as heterotrophic flagellates (Andersson et al. 1989, Nygaard \& Hessen 1990, Jones et al. 1993, Nygaard \& Tobiesen 1993, Keller et al. 1994). Abundance data, however, cannot be extrapolated easily to predation impact on natural picoplankton assemblages because the rates of ingestion by these species are often affected by factors other than prey abundance. It is also difficult to estimate the ecological benefit of phagotrophy to the algae because the behavior appears to serve different (and perhaps multiple) purposes for each species. Mixotrophy does not fit neatly into classical descriptions of 'primary producers' and 'consumers' that characterize most depictions of marine food webs, but instead imparts additional complexity to energy production, elemental flow and trophic relationships among pelagic microorganisms. A considerable effort will be required to properly understand the role of mixotrophy within natural microbial communities.

Acknowledgements. We thank the captain and crew of the RV 'Oceanus' for logistical and cruise support. J. B. Waterbury supplied the culture of Synechococcus used to prepare FLC. Three anonymous reviewers made helpful suggestions. This work was supported by National Science Foundation grants OCE-8901005 and DEB-9508571

\section{LITERATURE CITED}

Andersen P (1988) The quantitative importance of the 'microbial loop' in the marine pelagic: a case study from the North Bering/Chukchi seas. Arch Hydrobiol Beih Ergebn Limnol 31:243-251 
Andersson A, Falk S, Samuelsson G, Hagström $\AA$ (1989) Nutritional characteristics of a mixotrophic nanoflagellate, Ochromonas sp. Microb Ecol 17:251-262

Arenovski AL, Lim EL, Caron DA (1995) Mixotrophic nanoplankton in oligotrophic surface waters of the Sargasso Sea may employ phagotrophy to obtain major nutrients. J Plankton Res 17:801-820

Azam F, Fenchel T, Field JG, Meyer-Reil LA, Thingstad F (1983) The ecological role of water-column microbes in the sea. Mar Ecol Prog Ser 10:257-263

Bockstahler KR, Coats DW (1993) Grazing of the mixotrophic dinoflagellate Gymnodinium sanguineum on ciliate populations of Chesapeake Bay. Mar Biol 116:477-487

Boraas ME, Estep KW, Johnson PW. Sieburth JM (1988) Phagotrophic phototrophs: the ecological significance of mixotrophy. J Protozool 35:249-252

Boraas ME, Seale DB, Holen D (1992) Predatory behavior of Ochromonas analyzed with video microscopy. Arch Hydrobiol Beih Ergebn Limnol 123:459-468

Brooks DA (1996) Physical oceanography of the shelf and slope seas from Cape Hatteras to Georges Bank: a brief overview. In: Sherman K, Jaworski NA, Smayda TJ (eds) The northeast shelf ecosystem: assessment, sustainability, and management. Blackwell, Cambridge, p 47-74

Buck KR, Chavez FP, Campbell L. (1996) Basin-wide distributions of living carbon components and the inverted trophic pyramid of the central gyre of the North Atlantic Ocean, summer 1993. Aquat Microb Ecol 10:283-298

Burkill PH, Leakey RJG, Owens NJP, Mantoura RFC (1993) Synechococcus and its importance to the microbial foodweb of the northwest Indian Ocean. Deep-Sea Res 40: $773-782$

Campbell L, Carpenter EJ (1986) Estimating the grazing pressure of heterotrophic nanoplankton on Synechococcus spp. using the sea water dilution and selective inhibitor techniques. Mar Ecol Prog Ser 33:121-129

Campbell L. Vaulot D (1993) Photosynthetic picoplankton community structure in the subtropical North Pacific Ocean near Hawail (station ALOHA). Deep-Sea Res 40: 2043-2060

Campbell L, Nolla HA, Vaulot D (1994) The importance of Prochlorococcus to community structure in the central North Pacific Ocean. Limnol Oceanogr 39:954-961

Caron DA, Davis PG, Madin LP, Sieburth JM (1986) Enrichment of microbjal populations in macroaggregates (marine snow) from the surface waters of the North Atlantic. J Mar Res 44:543-565

Caron DA. Porter KG. Sanders RW (1990) Carbon, nitrogen. and phosphorus budgets for the mixotrophic phytoflagellate Poterioochromonas malhamensis (Chrysophyceae) during bacterial ingestion. Limnol Oceanogr 35:433-443

Caron DA, Lim EL, Miceli G, Waterbury JB, Valois FW (1991) Grazing and utilization of chroococcoid cyanobacteria and heterotrophic bacteria by protozoa in laboratory cultures and a coastal plankton community. Mar Ecol Prog Ser 76: $205-212$

Caron DA, Sanders RW, Lim EL, Marrasé C, Amaral LA, Whitney S, Aoki R, Porter KG (1993) Light-dependent phagotrophy in the freshwater mixotrophic chrysophyte Uinobryon cylindricum. Microb Ecol 25: 93-111

Caron DA, Dam HG, Kremer P, Lessard EJ, Madin LP, Malone TC, Napp JM, Peele ER, Roman MR, Youngbluth Mi (1995) The contribution of microorganisms to particulate carbon and nitrogen in the surface waters of the Sargasso Sea near Bermuda. Deep-Sea Res 42:943-972

Caron DA, Peele ER, Lim EL, Dennett MR (1999) Picoplankton and nanoplanktor and their trophic coupling in sur- face waters of the Sargasso Sea south of Bermuda. Limnol Oceanogr 44:259-272

Charpy L, Blanchot J (1998) Photosynthetic picoplankton in French Polynesian atoll lagoons: estimation of taxa contribution to biomass and production by flow cytometry. Mar Ecol Prog Ser 162:57-70

Chavez FP, Buck KR, Coale KH, Martin JH, DiTullio GR, Welschmeyer NA, Jacobson AC, Barber RT (1991) Growth rates, grazing, sinking, and iron limitation of equatorial Pacific phytoplankton. Limnol Oceanogr 36:1816-1833

Davis PG, Caron DA, Johnson PW, Sieburth JM (1985) Phototrophic and apochlorotic components of picoplankton and nanoplankton in the North Atlantic: geographic, vertical, seasonal and diel distributions. Mar Ecol Prog Ser 21 $15-26$

del Giorgio PA, Gasol JM, Vaqué D, Mura P, Agustí S, Duarte CM (1996) Bacterioplankton community structure: protists control net production and the proportion of active bacteria in a coastal marine community. Limnol Oceanogr 41 : $1169-1179$

Dolan JR, Gallegos CL (1991) Trophic coupling of rotifers, microflagellates, and bacteria during fall months in the Rhode River Estuary. Mar Ecol Prog Ser 77:147-156

Ferrier-Pagès C, Rassoulzadegan F (1994) Seasonal impact of the microzooplankton on pico- and nanoplankton growth rates in the northwest Mediterranean Sea. Mar Ecol Prog Ser 108:283-294

Fuhrman JA, Azam F (1982) Thymidine incorporation as a measure of heterotrophic bacterioplankton production in marine surface waters: evaluation and field results. Mar Biol 66:109-120

Fuhrman JA, McManus GB (1984) Do bacteria-sized marine eukaryotes consume significant bacterial production? Science 224:1257-1260

Fuhrman JA, Sleeter TD, Carlson CA, Proctor LM (1989) Dominance of bacterial biomass in the Sargasso Sea and its ecological implications. Mar Ecol Prog Ser 57:207-217

Gifford DJ (1988) Impact of grazing microzooplankton in the Northwest Arm of Halifax Harbour, Nova Scotia. Mar Ecol Prog Ser 47:249-258

Glover HE, Prézelin BB, Campbell L, Wyman M (1988) Picoand ultraplankton Sargasso Sea communitics: variability and comparative distributions of Synechococcus spp. and algae. Mar Ecol Prog Ser 49:127-139

Goericke R, Welschmeyer, NA (1993) The marine prochlorophyte Prochlorococcus contributes significantly to phytoplankton biomass and primary production in the Sargasso Sea. Deep-Sea Res 40:2283-2294

Hagström A, Azam F, Andersson A, Wikner J, Rassoulzadegan F (1.988) Microbial loop in an oligotrophic pelagic marine ecosystem: possible roles of cyanobacteria and nanoflagellates in the organic fluxes. Mar Ecol Prog Ser 49:171-178

Hall JA, Barrett DP, James MR (1993) The importance of phytoflagellate, heterotrophic flagellate and ciliate grazing on bacteria and picophytoplankton sized prey in a coastal marine enviromment. J Plankton Res 15:1075-1086

Havskum H. Hansen AS (1997) Importance of pigmented and colourless nano-sized protists as grazers on nanoplankton in a phosphate-depleted Norwegian fjord and in enclosures. Aquat Microb Ecol 12:139-151

Havskum H, Riemann B (1996) Ecological importance of bacterivorous, pigmented flagellates (mixotrophs) in the Bay of Aarhus, Denmark. Mar Ecol Prog Ser 137:251-263

Hobbie JE, Novitski TJ, Rublee PA, Ferguson RL, Palumbo AV (1987) Microbiology. In: Backus RH led) Georges Bank. MIT Press, Cambridge, p 247-251

Jacobson DM, Anderson DM (1996) Widespread phagocytosis 
of ciliates and other protists by marine mixotrophic and heterotrophic thecate dinoflagellates. J Phycol 32:279-285 Jones HLJ, Leadbeater BSC, Green, JC (1993) Mixotrophy in marine species of Chrysochromulina (Prymnesiophyceae) ingestion and digestion of a small green flagellate. J Mar Biol Assoc UK 73:283-296

Keller MD, Shapiro LP, Haugen EM, Cucci TL, Sherr EB, Sherr BF (1994) Phagotrophy of fluorescently labeled bacteria by an oceanic phytoplankter. Microb Ecol 28:39-52

Kimura B, Ishida Y (1989) Phospholipid as a growth factor of Uroglena amenicana, a red tide chrysophyceae in Lake Biwa. Nippon Suisan Gakkaishi 55:799-804

Kuuppo-Leinikki P, Autio R. Höllfors S, Kuosa H, Kuparinen J, Pajuniemi R (1994) Trophic interactions and carbon flow between picoplankton and protozod in pelagic enclosures manipulated with nutrients and a top predator. Mar Ecol Prog Ser 107:89-102

Landry MR, Kirshtein J, Constantinou J (1995) A refined dilution technique for measuring the community grazing impact of microzooplankton, with experimental tests in the central equatorial Pacific. Mar Ecol Prog Ser 120:53-63

Landry MR, Kirshtein J, Constantinou J (1996) Abundances and distributions of picoplankton populations in the central equatorial Pacific from $12^{\circ} \mathrm{N}$ to $12^{\circ} \mathrm{S}, 140^{\circ} \mathrm{W}$. DeepSea Res 43:871-890

Latasa M, Landry MR, Schlüter L, Bidigare RR (1997) Pigmentspecific growth and grazing rates of phytoplankton in the central equatorial Pacific. Limnol Oceanogr 42:289-298

Lessard EJ, Murrell MC (1998) Microzooplankton herbivory and phytoplankton growth in the northwestern Sargasso Sea. Aquat Microb Ecol 16:173-188

Li WKW, Subba Rao DV, Harrison WG, Smith JC, Cullen JJ, Irwin B, Platt T (1983) Autotrophic picoplankton in the tropical ocean. Science 219:292-295

Li WKW, Dickie PM, Irwin BD, Wood AM (1992) Biomass of bacteria, cyanobacteria, prochlorophytes and photosynthetic eukaryotes in the Sargasso Sea. Deep-Sea Res 39:501-519

Marrasé C, Lim EL, Caron DA (1992) Seasonal and daily changes in bacterivory in a coastal plankton community. Mar Ecol Prog Ser 82:281-289

McManus GB, Fuhrman JA (1988) Clearance of bacteriasized particles by natural populations of nanoplankton in the Chesapeake Bay outflow plume. Mar Ecol Prog Ser 42: $199-206$

Monger BC, Landry MR (1992) Size-selective grazing by heterotrophic nanoflagellates: an analysis using live-stained bacteria and dual-beam flow cytometry. Arch Hydrobiol Beih Ergebn Limnol 37:173-185

Murphy LS, Haugen EM (1985) The distribution and abundance of phototrophic ultraplankton in the North Atlantic. Limnol Oceanogr 30:47-58

Nygaard K, Hessen DO (1990) Use of ${ }^{14} \mathrm{C}$-protein-labeled bacteria for estimating clearance rates by heterotrophic and mixotrophic flagellates. Mar Ecol Prog Ser 68:7-14

Nygaard K, Tobiesen A (1993) Bacterivory in algae: a survival strategy during nutrient limitation. Limnol Oceanogr 38: 273-279

Olson RJ, Chisholm SW, Zettler ER, Altabet MA, Dusenberry JA (1990) Spatial and temporal distributions of prochlorophyte picoplankton in the North Atlantic Ocean. DeepSea Res 37:1033-1051

Pace ML, McManus GB, Findlay SEG (1990) Planktonic community structure determines the fate of bacterial production in a temperate Iake. Limnol Oceanogr 35:795-808

Porter KG, Feig YS (1980) The use of DAPI for identifying and counting aquatic microflora. Limnol Oceanogr 25:943-948

Reckermann M, Veldhuis MJW (1997) Trophic interactions between picophytoplankton and micro- and nanozooplankton in the western Arabian Sea during the NE monsoon 1993. Aquat Microb Ecol 12:263-273

Rothhaupt KO (1996) Utilization of substitutable carbon and phosphorus sources by the mixotrophic chrysophyte Ochromonas sp. Ecology 73:706-715

Rublee PA, Gallegos CL (1989) Use of fluorescently labelled algae (FLA) to estimate microzooplankton grazing. Mar Ecol Prog Ser 51:221-227

Safi KA, Hall JA (1999) Mixotrophic and heterotrophic nanoflagellate grazing in the convergence zone east of New Zealand. Aquat Microb Ecol 20:83-93

Sanders RW (1991) Mixotrophic protists in marine and treshwater ecosystems. J Protozool 38:76-81

Sanders RW, Porter KG, Caron DA (1990) Relationship between phototrophy and phagotrophy in the mixotrophic chrysophyte Poterioochromonas malhamensis. Microb Ecol 19:97-109

Sanders RW, Caron DA, Berninger UG (1992) Relationships between bacteria and heterotrophic nanoplankton in marine and fresh waters: an inter-ecosystem comparison. Mar Ecol Prog Ser 86:1-14

Sherman K, Grosslein M, Mountain D, Busch D, O'Reilly J, Theroux R (1996) The northeast shelf ecosystem: an initial perspective. In: Sherman K, Jaworski NA, Smayda TJ (eds) The northeast shelf ecosystem: assessment, sustainability. and management. Blackwell, Cambridge, p 103-126

Sherr BF, Sherr EB (1991) Proportional distribution of total numbers, biovolume, and bacterivory among size classes of 2-20 $\mu \mathrm{m}$ nonpigmented marine flagellates. Mar Microb Food Webs 5:227-237

Sherr BF, Sherr EB, Newell SY (1984) Abundance and productivity of heterotrophic nanoplankton in Georgia coastal waters. J Plankton Res 6:195-202

Sherr BF, Sherr EB, Pedrós-Alió C (1989) Simultaneous measurement of bacterioplankton production and protozoan bacterivory in estuarine water. Mar Ecol Prog Ser 54:209-219

Sherr EB, Sherr BF (1993) Protistan grazing rates via uptake of fluorescently labeled prey. In: Kemp PF, Sherr BF, Sherr EB, Cole JJ (eds) Handbook of methods in aquatic microbial ecology. Lewis Publishers, Boca Raton, p 695-701

Sherr EB, Sherr BF (1994) Bacterivory and herbivory: key roles of phagotrophic protists in pelagic food webs. Microb Ecol 28:223-235

Shiah FK, Ducklow HW (1995) Regulation of bacterial abundance and production by substrate supply and bacterivory: a mesocosm study. Microb Ecol 30:239-255

Stoecker DK (1998) Conceptual models of mixotrophy in planktonic protists and some ecological and evolutionary implications. Eur J Protistol 34:281-290

Stoecker DK, Taniguchi A, Michaels AE (1989) Abundance of autotrophic, mixotrophic and heterotrophic planktonic ciliates in shelf and slope waters. Mar Ecol Prog Ser 50:241-254

Stoecker DK, Sieracki ME, Verity PG, Michaels AE, Haugen E, Burkill PH, Edwards ES (1.994) Nanoplankton and protozoan microzooplankton during the JGOFS North Atlantic bloom experiment: 1989 and 1990. J Mar Biol Assoc UK 74:427-443

Suzuki T, Yamada N, Taniguchi A (1998) Standing crops of planktonic ciliates and nanoplankton in oceanic waters of the western Pacific. Aquat Microb Ecol 14:49-58

Thingstad TF, Havskum H, Garde K, Riemann B (1996) On the strategy of 'eating your competitor': a mathematical analysis of algal mixotrophy. Ecology 77:2108-2118

Waterbury JB, Watson SW, Guillard RRL, Brand LE (1979) Widespread occurrence of a unicellular, marine, planktonic, cyanobacterium. Nature 277:293-294 
Weisse T (1989) The microbial loop in the Red Sea: dynamics of pelagic bacteria and heterotrophic nanoflagellates. Mar Ecol Prog Ser 55:241-250

Weisse T, Scheffel-Möser U (1991) Uncoupling the microbial loop: growth and grazing loss rates of bacteria and heterotrophic nanoflagellates in the North Atlantic. Mar Ecol Prog Ser 71:195-205

Wiebe PH, Beardsley RC (1996) Physical-biological interactions on Georges Bank and its environs. Deep-Sea Res 43: $1437-1438$

Editorial responsibility: Diane Stoecker (Contributing Editorl, Cambridge, Maryland, USA
Wikner J, Rassoulzadegan F, Hagström $\AA$ (1990) Periodic bacterivore activity balances bacterial growth in the marine environment. Limnol Oceanogr 35:313-324

Wright RT, Coffin RB (1984) Measuring microzooplankton grazing on planktonic marine bacteria by its impact on bacterial production. Microb Ecol 10:137-149

Zohary T, Robarts R (1992) Bacterial numbers, bacterial production, and heterotrophic nanoplankton abundance in a warm core eddy in the eastern Mediterranean. Mar Ecol Prog Ser 84:133-137

Submitted: December 14, 1998; Accepted: June 8, 1999 Proofs received from author(s): December 28, 1999 